\title{
MISTIKISME DAN ALQURAN: MAKNA SIMBOLIK PENYEMBUHAN KESURUPAN PADA KESENIAN KUBROSISWO BINTANG MUDO
}

\author{
Farid Hasan \\ Institut Agama Islam Negeri Salatiga \\ faridhasan.m.hum@gmail.com
}

\begin{abstract}
The article addresses the tranced healing phenomena by locating it as a symbolic manifestation of culture that is related to the mystical symbolism and the Qur'an. The research aims to answer the question of what is the meaning of the tranced healing phenomena in the Kubrosiswo Bintang Mudo art show in its mystical symbolism context? By using qualitative method and semiotic approach, I argue that tranced healing phenomena is perceived as encountering two sources of strength, the black power which is coming from Satan, and the holy power which is coming from God. The success of healing the possessed people by using the verses of the Qur'an means a symbolic form of the power of the batil which is occupied by the rightly (haqq) power. This affirms a dominative power of God, because humans as ordinary people in their weaknesses of their physical body, when devoting unto God, then it is believed that there is no malevolent strength which is able to impair. In other words, healing is a symbolic manifestation of the nobility of human's faith unto God.
\end{abstract}

Keywords: Living Qur'an, tranced healing, verses of the Qur'an, mysticism

Abstrak: Tulisan ini mengkaji fenomena penyembuhan kesurupan dengan mendudukannya sebagai manifestasi simbolik kebudayaan yang berelasi dengan mistikisme dan Ayat-ayat Alquran. Tulisan ini berangkat dari pertanyaan, apa sebenarnya makna fenomena penyembuhan kesurupan pada pertunjukan kesenian Kubrosiswo Bintang Mudo dalam konteks simbolik tersebut? Dengan menggunakan metode kualitatif dan pendekatan semiotik, tulisan ini berargumen bahwa penyembuhan kesurupan dipahami sebagai pertemuan antara dua kekuatan, yaitu kekuatan hitam (bätil) yang bersumber dari setan dan kekuatan suci (haq) yang bersumber dari Tuhan. Keberhasilan penyembuhan kesurupan menggunakan ayatayat Alquran merupakan bentuk simbolik ditundukkannya kekuatan 
yang batitil oleh kekuatan yang haq. Ini menjadi bentuk penegasan sebuah kekuasaan yang dominatif, sebab manusia sebagai insan biasa dengan kelemahan fisiknya, ketika menyerahkan diri kepada Tuhan, maka diyakini tidak ada kekuatan bätil yang mampu menyakiti. Dengan kata lain, penyembuhan kesurupan merupakan manifestasi simbolik keluhuran keimanan manusia kepada Sang Pencipta.

Kata kunci: Living Quran, penyembuhan kesurupan, ayat-ayat Alquran, Mistikisme.

\section{Pendahuluan}

Kesurupan merupakan fenomena yang sering dialami masyarakat secara tiba-tiba dan terjadi dalam setiap kebudayaan di dunia. Dalam kasus masyarakat Jawa, menurut Margaret T. Kartomi, fenomena ini kemungkinan besar telah ada sejak lama dan keberadaannya mungkin sama tuanya dengan masyarakat itu sendiri. ${ }^{1}$ Dalam bingkai ini, maka jelas pernyataan tersebut mengasumsikan bahwa kesurupan merupakan sebuah fenomena kebudayaan manusia yang akan selalu ada di mana dan kapanpun masyarakat itu ada.

Sebagai sebuah fenomena budaya, menurut perspektif kesehatan, kesurupan dapat dipandang sebagai kondisi "sakit", yaitu sebuah kondisi kejiwaan yang abnormal. Orang yang kesurupan akan memperlihatkan berbagai macam keanehan, baik dalam sikap maupun tindakan yang notabenenya berada di luar kendali manusia. Berbagai macam tindakan yang tidak mungkin dilakukan orang dalam kondisi kejiwaan normal, dapat dilakukan pada saat kesurupan.

Dalam pandangan kultur masyarakat Jawa, sakit tidak bisa begitu saja dipandang secara materialis bahwa itu merupakan gangguan kesehatan fisik yang disebabkan oleh faktor-faktor empirik. Sejauh panca indera masih menjangkau faktor-faktor penyebab dari sakit, maka sakit dalam batas tertentu masih dipahami dalam tataran indrawi. Namun, jika sakit tersebut sudah tidak lagi terjangkau, orang Jawa umumnya akan mengembalikan faktor penyebab sakit tersebut pada hal-hal yang bersifat metafisik. Misalnya, penyakit tertentu yang dianggap karena gangguan makhluk halus, setan maupun penguasa kegaiban (danyang) pada tempat-tempat tertentu.

Pada saat agama Islam masuk ke masyarakat Jawa, sebenarnya telah terjadi transformasi pandangan masyarakat dalam melihat

${ }^{1}$ Margaret T. Kartomi, "Music and Trance in Central Java," dalam Ethnomusicology, Vol. 17, No. 2 (1973), 163-208. 
penyakit. Seiring dengan perubahan kepercayaan, penyebab sakit tidak lagi dipandang berasal dari makhluk halus, melainkan merupakan ketetapan dari Allah. Segala hal dalam kehidupan ini, baik itu kesenangan maupun kesusahan semuanya dipandang kembali kepadaNya sebagai causa prima kehidupan ${ }^{2}$. Oleh sebab itu, dalam konteks penyembuhan orang sakit, masyarakat kerap merespon secara teologis dengan mengembalikan pada kekuasaan-Nya.

Penyembuhan orang sakit yang direlasikan kepada keberadaan Allah dapat dilihat dari berbagai macam upaya masyarakat dalam bentuk penggunaan ayat-ayat Alquran sebagai sarana penyembuhan. Berbagai macam kajian juga telah berupaya menjelaskan keberadaan fenomena ini. Sebagian besar memaknainya dari pendekatan fungsional, yaitu dengan mengatakan bahwa ayat-ayat Alquran memiliki fungsi penyembuhan bagi orang-orang yang sedang sakit maupun fungsi sosial bagi masyarakat di sekitarnya ${ }^{3}$.

Namun, apabila melihat fakta-fakta pada fenomena orang kesurupan yang terjadi pada pertunjukan kesenian Kubrosiswo Bintang Mudo ${ }^{4}$ di Dusun Ngloho, Desa Pringsurat, di mana orang-

2Di dalam Alquran terdapat beberapa ayat yang secara eksplisit maupun implisit menerangkan bahwa Allah adalah causa prima kehidupan. Segala hal dalam kehidupan dunia ini dapat dikembalikan kepada Allah, sebab Allah yang pada dasarnya menjadi penentu utama gerak kehidupan manusia. Hal ini bisa terlihat dalam QS al-Baqarah [2]: 156, bahwa sesungguhnya segala sesuatu adalah milik Allah dan hanya kepada-Nya segala sesuatu akan kembali.

${ }^{3}$ Abdul Hadi, "Bacaan Al-Qur'an sebagai Pengobatan: Studi Living Qur'an Pada Praktik Pengobatan di Ds. Keben Kec. Turi Kab. Lamongan Jawa Timur," Skripsi, Fakultas Ushuluddin dan Pemikiran Islam, UIN Sunan Kalijaga, 2015; Baytul Muktadin, "Untuk Pengobatan Penyakit Jiwa: Studi Living Qur'an di Desa Kalisabuk Kesugihan Cilacap Jawa Tengah," Tesis, Pascasarjana UIN Sunan Kalijaga, 2015; Ahmad Faidi, "Qashidah Burdah sebagai Media Pengobatan MagisEkonomis: Studi terhadap Tradisi Pembacaan Qashidah Burdah terhadap Orang Sakit di Desa Sera Timur Kecamatan Bluto Kabupaten Sumenep Propinsi Jawa Timur," dalam Millati Journal of Islamic Studies and Humanities, Vol. 1, No. 1 (2016), 61-79.

${ }^{4}$ Kubrosiswo merupakan salah satu jenis kesenian tradisional yang tersebar di wilayah Karesidenan Kedu Jawa Tengah dan sebagian wilayah Yogyakarta. Kesenian ini menurut Machmoed Effendie, pada awalnya berasal dari Desa Mendut Kecamatan Mungkid Kabupaten Magelang, yang diciptakan oleh seniman santri sekitar tahun 1960-an. Awalnya adalah kegiatan bela diri kaum pemuda, tetapi lambat laun berubah menjadi corak kesenian tradisional yang memadukan unsurunsur petani Jawa dan nilai-nilai keislaman. Lihat, Machmoed Effendie, "Unsur Budaya Santri dalam Seni: Studi Pendahuluan Tentang Seni Pertunjukan Rakyat Kobra Siswa Di Magelang," dalam Laporan Penelitian, Fakultas Ilmu Budaya, UGM, 2001. Adapun menurut Setiorini Rahma Safitri, khususnya di Dusun Ngloho Desa 
orang yang kesurupan akan melakukan tindakan-tindakan yang tidak wajar, seperti makan kaca, makan genting, makan bara api hingga bertindak secara brutal, ${ }^{5}$ maka pendekatan fungsional ini tidak cukup tepat. Pertama, terdapat fakta sosial bahwa kesurupan oleh masyarakat pendukung kesenian tersebut dianggap sebagai kondisi tidak sadar diri yang disebabkan oleh setan, makhluk jahat dalam terminologi mereka. Kedua, adanya pernyataan yang menyatakan bahwa ayat-ayat Alquran memiliki khadam yang berasal dari Allah yang merupakan simbol kekuatan kebaikan dan kebenaran. ${ }^{6}$ Artinya, ketika orang kesurupan disembuhkan menggunakan ayat-ayat Alquran, sebenarnya terdapat dua kekuatan yang bertemu, yaitu kekuatan setan dan kekuatan Allah atau kekuatan yang ḥaqq bertemu dengan kekuatan yang bạtil.

Artikel ini hendak mengulik fenomena penyembuhan kesurupan di pertunjukan kesenian Kubrosiswo Bintang Mudo dengan mendudukan fenomena tersebut sebagai simbol budaya yang mengandung makna tertentu, sekaligus mendeskripsikan bagaimana simbol tersebut dimaknai dan difungsikan oleh masyarakat.

\section{Makna Alquran dalam Kehidupan Umat Muslim}

Umat Islam selalu meyakini salah satu diktum bahwa Alquran merupakan ktiab suci yang sälị li kull zamān wa makān (selalu sesuai bagi setiap waktu dan tempat). ${ }^{7}$ Mereka meyakini bahwa Alquran merupakan kalam Allah yang diturunkan sebagai petunjuk (budāa bagi

Pringsurat Kabupaten Temanggung, kesenian kubrosiwo merupakan bentuk seni tradisional yang dimiliki oleh secara kolektif oleh warga Dusun Ngloho Desa Pringsurat Kabupaten Temanggung dan telah ada sejak tahun 1989 dengan nama Kubrosiswo Bintang Mudo. Setiorini Rahma Safitri, "Apresiasi Masyarakat Santri Ngloho Terhadap Kesenian Kubrosiswo Bintang Mudo Di Ngloho Pringsurat Temanggung," Tesis, Program Pascasarjanan, UNNES, 2017.

${ }^{5}$ Wawancara dengan Muhammad Faizin, Ketua Kelompok Kesenian Kubrosiswo Bintang Muda pada 4 Mei 2019 di Dusun Ngloho Desa Pringsurat Kabupaten Temanggung.

"Safitri, "Apresiasi Masyarakat Santri”, 121.

${ }^{7}$ Upaya untuk menunjukkan kesesuaian Alquran dengan zaman dan waktu selalu diupayakan oleh para mufasir, terutama mereka yang memperjuangkan korelasi antara dimnesi historis dengan dimensi kontekstual. M. 'Ābid al-Jābiri memiliki tawaran "ja'l al-maqu' mu'äsir li nafsib wa mu'asisir lana", menjadikan Alquran kontekstual pada zamannya serta kontekstual bagi kita. Hasan Mahfudh, "Dari "Ābid al-Jābirīi tentang Epistemologi Arab Islam," dalam Dialogia: Jurnal Studi Islam dan Sosial, Vol. 13. No. 1 (2015), 4. 
umat manusia yang dapat menyelamatkannya hingga akhir zaman. ${ }^{8}$ Alquran juga diyakini sebagai mukjizat abadi karena Alquran memiliki keunggulan yang mampu melemahkan para penentangnya. ' Selain itu, umat Islam juga meyakini bahwa Alquran mampu berfungsi sebagai shifä, (obat) yang banyak dipraktikkan untuk menyembuhkan orang sakit, baik sakit jasmani ataupun ruhani. ${ }^{10}$

Menurut Quraish Shihab, seseorang yang membaca Alquran bisa saja terinspirasi untuk mengungkapkan gambarannya sendiri tentang Alquran. Namun menurutnya, sebagaimana sabda Rasulullah, Alquran merupakan jamuan Tuhan, sehingga akan rugi bagi siapa saja yang tidak menghadiri jamuan-Nya, dan lebih rugi lagi bagi mereka yang hadir namun tidak menyantapnya. ${ }^{11}$ Selain itu, dia juga mengatakan bahwa ayat-ayat Alquran dapat ibaratkan sebagai intan, yang setiap sudutnya memancarkan cahaya yang berbeda dengan apa yang terpancar dari sudut-sudut lainnya. Oleh sebab itu, dia juga mengatakan bahwa tidak mustahil bila orang lain diminta memandangnya, maka mereka akan melihat lebih banyak dari apa yang dilihat oleh peminta. ${ }^{12}$

Menurut Muhammad Iqbal, sebagaimana dikutip oleh Muhammad Mansur, Alquran merupakan kitab yang lebih mengutamakan amal daripada gagasan. Alquran dalam pandangan Bashar b. al-Sura juga diibaratkan sebagai buah kurma yang setiap kali dikunyah, manisnya akan semakin manis. Sedang menurut Imām alShäfíi dalam kitabnya 'I'jäz, al-Bayān fì Suwar al-Qur'an menyatakan bahwa Alquran merupakan pedoman bagi umat Islam. ${ }^{13}$

Berdasarkan uraian-uraian di atas terdapat berbagai macam makna Alquran. Namun, terdapat benang merah yang dapat menghubungkan makna-makna tersebut, yaitu bahwa umat muslim sangat mengagungkan Alquran sebagai kitab sucinya. Kitab ini dianggap sebagai intan, cahaya, kabar gembira, sesuatu yang memberikan nikmat dan yang terpenting adalah menjadi petunjuk dan

\footnotetext{
${ }^{8}$ QS. Al-Baqarah [2]: 2.

${ }^{9}$ Muhammad Quraish Shihab, Mukjizat Al-Quran (Bandung: Mizan, 2001).

${ }^{10}$ Kata shifa' (obat/penawar) dalam Alquran dapat dilihat dalam QS. Yūnus [10]: 57, QS. al-Naḥl [16]: 69, QS. al-Isrā' [17]: 82, QS. al-Shu'arā' [26]: 80 dan QS. Fuṣșilat [41]: 44.

${ }^{11}$ Muhammad Quraish Shihab, Membumikan Al-Quran (Bandung: Mizan, 1992), ii.

${ }^{12}$ Ibid., 138.

${ }^{13}$ Muhammad Mansur, dkk., Metodologi Penelitian Living Qur'an dan Hadis (Yogyakarta: Teras, 2007), 28-29.
} 
pedoman umat Islam dalam mengarungi hidupnya. Hal ini menjadi jelas, bahwa Alquran juga dimaknai sebagai obat atau penawar, sehingga secara praksis ayat-ayat Alquran tersebut dianggap memiliki fungsi bagi pemecah kebuntuan masalah kehidupan manusia.

\section{Sejarah Kesenian Kubrosiswo Bintang Mudo}

Kubrosiswo pada dasarnya adalah kesenian tradisional, sebab ia membawa nilai-nilai tradisi yang telah turun temurun dalam budaya masyarakat pedesaan Jawa. Misalnya, kehidupan petani, semangat ibadah dan nilai kebangsaan. Hal ini tampak jelas dari syair-syair lagu yang digunakan maupun gerak tarinya. ${ }^{14}$

Sebagai sebuah istilah, kubrosiswo berasal dari dua kata, yaitu "kubro" dan "siswo". "Kubro" artinya "besar", sedangkan "siswo" berarti "murid". Istilah ini sering dimaknai sebagai murid yang selalu menjunjung tinggi kebesaran Tuhan. Versi lain mengatakan bahwa "kubro" adalah akronim dari "ubahing badan lan rogo", mengacu kepada kesenian yang bukan hanya menggerakkan badan, tetapi juga jiwa, yang mana maksud secara filosofisnya, yaitu penyelarasan aspek dunia dan akhirat. ${ }^{15}$

Kesenian Kubrosiswo muncul pertama kali pada tahun 1960-an di Dusun Cabean, Desa Mendul, Kabupaten Magelang. Awalnya adalah sebuah kegiatan beladiri yang dibuat dengan maksud sebagai wadah bagi pemuda agar mereka tidak terjerumus ke dalam penyebaran paham komunisme. Dimotori oleh empat orang seniman santri yang bernama: Amin Hamzah, Muchlan, Hasyim dan M. Bisyri dan lambat laun berubah menjadi kesenian. ${ }^{16}$

Dari Mendut, kesenian kubrosiswo kemudian tersebar luas ke daerah lain di Magelang, dan kota-kota lain seperti Yogyakarta dan Temanggung. Di Ngloho, kesenian ini masuk pada tahun 1989 yang dibawa oleh seorang bernama Widi. Ia adalah orang Nipis daerah Grabag Kabupaten Magelang. Bersama saudaranya yang bernama Narto, Samsi dan Jumadi mereka mengajarkan pemuda-pemuda Ngloho untuk bermain kesenian. Antusias pemuda saat itu cukup tinggi karena mereka merasa ada kekosongan dalam bergiat seni di dusunnya. Kondisi ini dipicu oleh dua hal, yaitu: 1) tidak ada kesenian

${ }^{14}$ Effendhie, "Unsur Budaya Santri”.

${ }^{15}$ Jihan Burhannudin, "Identitas Kesenian Tradisional Kubro Siswo Di Dusun Sedayu II, Sedayu, Muntilan, Magelang," Skripsi, Universitas Islam Negeri Sunan Kalijaga, 2016, 2.

${ }^{16}$ Effendhie, "Unsur Budaya Santri," 15-16. 
yang dianggap representatif bagi pemenuhan estetika seni anak muda; 2) selama ini Ngloho hanya menjadi penonton di tengah-tengah keramaian berkesenian di lingkungan perdusunan sekitarnya. ${ }^{17}$

Sebelum kubrosiswo masuk ke Ngloho, di dusun tersebut terdapat kesenian yang disebut manoronan. Seni ini semacam rebana yang menggunakan alat-alat perkusi berupa terbang, tetapi syair-syair lagu yang dinyanyikan berbahasa Jawa. Cengkok nada yang dinyanyikan juga khas nada pentatonik Jawa. Adapun pesan-pesan dalam seni ini bersifat Islami. Jadi kesenian ini merupakan gabungan antara budaya Arab dan Jawa. Tidak ada koreografi dalam artian gerak tari. Mungkin saja ini terkait dengan masalah etika berkesenian yang sebenarnya seni bukan untuk tujuan hura-hura, tetapi bentuk pengabdian kepada Allah, sehingga harus ditampilkan secara santun ${ }^{18}$.

Dalam konteks masyarakat Ngloho masa itu, ukuran etika berkesenian memang terletak pada gerak tubuh pemainnya. Menurut warga sekitar dulu ada pandangan bahwa seni yang beradab adalah seni yang tidak berjoget. Seni yang berjoget seperti jatbilan, soreng, prajuritan dan sebagainya yang banyak muncul di Desa Pringsurat, dalam batas tertentu dianggap tidak masuk dalam ukuran etika berkesenian orang-orang Ngloho. Orang-orang Ngloho kadang melabeli seni yang demikian ini dengan istilah jogedan, sebuah pelabelan peyoratif yang memiliki nilai rendah secara etika Islami yang hidup dalam masyarakat tersebut ${ }^{19}$.

Pandangan seperti yang telah dijelaskan di atas sebenarnya lebih merepresentasikan pandangan kelompok tua. Adapun anak muda Ngloho cukup berbeda. Ketika kubrosiswo datang hampir semua anak muda terlibat dalam kegiatan ini, baik sebagai penari, pemain musik maupun hanya sekedar menjadi kru. Dari segi kebutuhan estetis mereka menganggap kesenian manoro yang "beradab" sudah ketinggalan jaman. Karena tidak adanya gerak tari, maka kesenian tersebut dianggap tidak bisa lagi memenuhi kebutuhan anak muda yang sedang energik dalam masa perkembangan. Namun, dengan berkesenian kubrosiswo, pada dasarnya mereka sedang berkesenian jogedan, seni yang tidak sesuai etika Islami masyarakat Ngloho. Dalam batas ini, etika berkesenian yang "beradab" tersebut mulai

\footnotetext{
${ }^{17}$ Safitri. “Apresiasi Masyarakat Santri,” 124-125.

${ }^{18}$ Wawancara dengan Panis Dhbi Salam, Sekretaris Kubrosiswo Bintang Mudo di Ngloho, Pringsurat, Temanggung pada 15 Juni 2019.

${ }^{19 S}$ Safitri, "Apresiasi Masyarakat Santri," 128.
} 
terdekonstruksi oleh tindakan berseni anak muda yang memiliki preferensi seni berbeda. Akibatnya pada pertengahan tahun 1990-an, dapat dikatakan sebagai batas akhir eksistensi manoro di Ngloho, sebab generasi muda kemudian lebih memilih berkesenian kubrosiswo, ketimbang harus meneruskan manoro. ${ }^{20}$

Selain adanya hasrat untuk memenuhi kebutuhan estetis, kubrosiswo dengan mudah masuk ke Ngloho karena seni tradisional pada tahun 1990-an sedang menjadi trend di wilayah Pringsurat, seperti jathilan, kuda lumping, soreng, reyok dan sebagainya. Berkesenian ini pada masa tersebut bukan hanya masalah berkegiatan seni, tetapi, sebagaimana dikatakan Setiorini Rahma Safitri, ia telah menjadi bagian dari gaya hidup anak muda. Sebagai gaya hidup, seni berkelindan dengan masalah status sosial, sehingga akan melahirkan penghormatan atasnya. Dalam psikologi kekuasaan, seni secara komunikasi merupakan manifestasi ego individu untuk berkuasa atas yang lain. Menjadi sebuah kebanggaan ketika individu dianggap memiliki keunggulan dibandingkan yang lainnya karena atribut kesenian yang dimilikinya. ${ }^{21}$

Preferensi akan status sosial ini yang dengan cepat menjadikan Widi dan saudaranya diidolakan dan dengan mudah diterima oleh warga Ngloho. Sehingga pelatihan kesenian yang dia lakukan dapat berkelanjutan. Tidak luput pula bagi anak muda yang sedang membutuhkan jati diri, maka kubrosiswo dianggap pilihan yang pas dalam melengkapi status sosial dirinya. Pujian akan pemain yang sangar (keren) karena dapat melakukan hal-hal yang orang lain tidak dapat lakukan menjadi kebanggaan dan bentuk pencapaian tersendiri. ${ }^{22}$

Ketika kubrosiswo diterima oleh anak muda, kesenian ini kemudian diberi nama Bintang Mudo. "Bintang" maksudnya, "bintang" dan "mudo" artinya "anak muda". Tidak jelas mengapa diberi nama demikian. Namun, di tempat lain juga ditemui penyebutan kelompok kesenian ini dengan nama yang mirip, seperti

\footnotetext{
${ }^{20}$ Wawancara dengan Muhammad Shodikin (warga Ngloho) dan Setiorini Rahma Safitri (peneliti Kubrosiswo Bintang Mudo) di Ngloho, Pringsurat, Temanggung pada 15 Juni 2019. Sebagai catatan, rumah Muhammad Shodikin pada tahun 1990an dijadikan camp kesenian Manoro dan almarhum ayahnya adalah salah satu anggotanya.

${ }^{21}$ Wawancara dengan Setiorini Rahma Safitri, peneliti Kubrosiswo Bintang Mudo di Ngloho, Pringsurat, Temanggung pada 15 Juni 2019.

${ }^{22}$ Untuk analisa tentang status sosial dalam kesenian Kubrosiswo Bintang Mudo ini dapat dilihat dalam Safitri, "Apresiasi Masyarakat Santri," 120.
} 
sinar muda, cahaya muda, dan sebagainya. Nampaknya, mengkaitkan cahaya (penerang) dengan anak muda menjadi kecenderungan umum. Mungkin saja dimaksudkan bahwa pada dasarnya kesenian ini bersifat Islami, yang di dalamnya terdapat syair-syair lagu yang berbentuk dakwah, ${ }^{23}$ sehingga agama yang dipahami sebagai petunjuk harus terekspresikan dalam berkesenian.

Dalam perkembangannya, kubrosiswo Bintang Mudo mengalami pasang surut. Masa kejayaan dapat dikatakan terjadi pada tahun 1990an. Kegiatan manggung banyak dilakukan, baik itu pesanan pemerintah pada perayaaan hari kemerdekaan, perlombaan seni, maupun pesanan hiburan dari masyarakat. Sejak krisis moneter tahun 1997 hingga satu dekade berikutnya, ia memasuki masa suram. Jarang sekali pertunjukkan ditampilkan. Kubrosiswo berada dalam posisi vakum karena menjamurnya saingan baru berupa hiburan televisi yang mulai menjamur pada pertengahan tahun 2000-an. Keberadaan televisi ini didukung oleh murahnya teknologi penangkap sinyal parabola yang mampu dibeli masyarakat desa. ${ }^{24}$

Di Ngloho, kubrosiswo kini hanya menjadi salah satu hiburan di antara hiburan lainnya. Sekalipun ia mulai aktif kembali pada tahun 2010 dengan penyegaran personil baru, tetapi ia semakin tertantang dengan munculnya hiburan yang lebih baru dan canggih, seperti gadget. Setiap orang kini bisa memilih hiburan sesuai dengan preferensinya. Dari seni, informasi, gaya hidup hingga olahraga tersaji semuanya. Akibatnya, jenis hiburan tradisional mulai tersingkir, tidak terkecuali kubrosiswo Bintang Mudo yang dapat dikatakan tertatih-tatih dalam menghadapi perkembangan zaman. ${ }^{25}$

\section{Mistikisme dalam Kesenian Kubrosiswo Bintang Mudo}

Lekatnya seni dengan mistik nampaknya merupakan satu seni estetika tersendiri yang ada di dunia timur. Seni seringkali terpahami secara antropologi sebagai bentuk dari ritual. ${ }^{26}$ Di Jawa, lekatnya seni dengan mistik hampir ditemui di setiap kesenian tradisional. ${ }^{27}$ Tidak

\footnotetext{
${ }^{23}$ Yulia Esti Katrini, "Siar Islam Dalam Kesenian Tradisional Di Esk Karesidenan Kedu," dalam Jurnal Penelitian Inovasi, vol. 26, no. 2 (2006), 222-234.

${ }^{24}$ Wawancara dengan Erwan Ladi Fani, tokoh pemuda di Ngloho, Pringsurat, Temanggung pada 15 Juni 2019.

${ }^{25}$ Wawancara dengan Panis Dhbi Salam pada 15 Juni 2019.

${ }^{26}$ Dharsono Sony Kartika, Pengantar Estetika (Bandung Rekayasa Sains, 2004).

${ }^{27}$ Kathy Foley, "The Dancer and the Danced: Trance Dance and Theatrical Performance in West Java," dalam Asian Theater Journal, Vol. 2, No. 1 (1985), 28-49.
} 
terkecuali dalam hal ini kesenian Kubrosiswo Bintang Mudo. Sekalipun kesenian ini bukanlah seni ritual, tetapi unsur-unsur mistik yang merupakan kecenderungan orang Jawa masuk di dalamnya. Mistikisme yang ditemukan dalam kesenian kubrosiswo secara umum merupakan manifestasi etika harmoni manusia dengan lingkungan kehidupan mereka. ${ }^{28}$

Berbagai macam ritual kegamaan yang sebelumnya telah ada pada dasarnya adalah manifestasi mistikisme Islam dalam pengalkuturasiannya dengan kebudayaan pra-Islam. Orientasi dasar masyarakat Jawa yang harmonis, ${ }^{29}$ membuat mereka begitu terbuka dengan kebudayaan pendatang. Tetapi dengan syarat kebudayaan tersebut dapat diadaptasikan dengan budaya yang telah ada sebelumnya.

Wacana ini menjadi sedemikian menarik, sebab diketahui bahwa kesenian kubrosiswo adalah kesenian yang diciptakan oleh seniman santri pada tahun 1960 -an. ${ }^{30}$ Sebagai seni islami, jangan dibayangkan mereka puritan dan terbebas dari mistikisme Jawa. Namun, hal tersebut tidak ditemukan dalam kesenian kubrosiswo. ${ }^{31}$ Sejauh ini tidak diketahui sejak kapan mistikisme muncul dalam kesenian tersebut. Hanya saja secara umum setiap kesenian kubrosiswo yang tersebar dapat dipastikan memiliki dimensi mistikisme Jawa. ${ }^{32}$

Terkait dengan staging, fakta menegaskan akan mistik tersebut. Kegiatan merias panggung di tiap sudutnya dengan dedaunan kuburan. Hal ini bukanlah sebuah asesoris yang sekedar memperindah, tetapi dianggap memiliki dimensi metafisik. Dedaunan yang digunakan ini biasanya: emas-emasan, andong abang, pakis dan daun kalongan. ${ }^{33}$ Daun-daun tersebut dianggap memiliki kekuatan gaib pengusir roh-roh jahat yang dapat membahayakan manusia. Pemasangannya pada empat penjuru mata angin panggung pertunjukan, mengingatkan doa-doa ritual Jawa yang selalu memohon

\footnotetext{
${ }^{28}$ Wawancara dengan Setiorini Rahma Safitri pada 20 Juli 2019.

${ }^{29}$ Terkait dengan etika harmonisme Jawa dapat dilihat dalam Franz Magnis Suseno, Etika Jawa: Sebuah Analisis Falsafi Tentang Kebijaksanaan Hidup Jawa (Jakarta: Gramedia, 1984).

${ }^{30}$ Burhannudin, "Identitas Kesenian Tradisional," 2.

${ }^{31}$ Sebagai sebuah bentuk budaya sebenarnya dapat dikatakan kesenian kubrosiswo merupakan wujud akulturatif berbagai kebudayaan antara Islam, Jawa dan kebangsaan. Safitri. “Apresiasi Masyarakat Santri," 57-78.

${ }^{32}$ Wawancara dengan Setiorini Rahma Safitri pada 27 Juli 2019.

${ }^{33}$ Wawancara dengan Tamrin, mantan penari kesenian Kubrosiswo Bintang Mudo di Ngloho, Pringsurat, Temanggung pada 27 Juli 2019.
} 
agar kekuatan jahat dari empat penjuru dunia bisa kembali ke asalnya. Ini artinya daun-daun tersebut difungsikan sebagai simbol tolak balak.

Menurut pengakuan lakon Kubrosiswo Bintang Mudo, daun tersebut dapat diperlukan guna menjinakan orang-orang yang kesurupan agar mudah diatasi. Kesurupan di satu sisi memang kemasan pertunjukan yang sangat menghibur karena menjadi daya tarik tersendiri bagi penglihatnya. Namun, di sisi lain kesurupan yang sulit disembuhkan menjadi beban bagi yang lain karena kadang harus menambah biaya. Terkait dengan ini, biasanya dilakukan pendekatan mistis agar tidak terjadi apa-apa demi kelancaran dan terutama adalah keselamatan.

Sebelum pertunjukan dilakukan kadangkala grup kesenian Kubrosiswo Bintang Mudo melakukan ritual pra-pertunjukan. Ritual ini berbentuk permohonan keselamatan dengan cara berziarah ke makam keramat desa, di mana tempat pertunjukan akan diselenggarakan. Makam ini akan disurvei terlebih dahulu untuk diidentifikasi, sehingga diyakini bahwa ia adalah makam pendiri desa. Pendiri desa ini sering disebut cikal bakal desa, leluhur yang diyakini telah melakukan bubak citak desa (membuka hutan untuk dijadikan hunian). Mereka biasanya dianggap sebagai pioner pejuang masa lalu yang berhasil menaklukan entitas gaib dari hutan tersebut. ${ }^{34}$ Leluhur yang bubak citak desa adalah mereka yang berhak mendapatkan persembahan karena mereka telah berada dalam tingkatan yang tidak lagi terikat akan fisik dunia. Namun, diyakini memiliki kekuatan yang mampu membawa kesejahteraan bagi keturunan atau pemujanya. Dalam konstruk budaya seperti ini, maka dapat dipahami mengapa terkadang kesenian kubrosiswo perlu melakukan ziarah ke makam keramat pendiri desa. ${ }^{35}$.

${ }^{34}$ Di masa lalu pembukaan hutan untuk dijadikan hunian tidak bisa dipandang sebagai kegiatan profan. Sebuah hutan biasanya diyakini tempat bersemayamnya kekuatan-kekuatan gaib. Hanya dengan menaklukan yang gaib tersebut dimungkinkan hutan tersebut dapat dibuka. Terkait pandangan ini bisa dilihat dalam fakta mental kisah pendirian keraton Surakarta dalam Sri Winarti P., Sekilas Sejarah Keraton Surakarta (Surakarta: Cendrawasih, t.th).

${ }^{35}$ Yang perlu dicatat, yaitu bahwa tidak semua warga Ngloho menyetujui tindakan ini. Ritual ini mendapatkan kritik keras dari kelompok-kelompok Ngloho yang dianggap keislamannya kuat. "Formalisme" Islam dalam tataran syariat di Ngloho sebenarnya mengalami penguatan sejak pasca G30S, yang ditandai hilangnya ritual sadranan yang dikemas secara Jawa, yang dulu dilakukan di tempat keramat desa yang beresensikan pemetrian (persembahan) kepada danyang-danyang desa, tetapi kemudian dirubah dalam penyederhanaan kemasan dan penggantian doa Jawa 
Selain ritual pra-pertunjukan, mistikisme juga ditemukan dalam keyakinan akan peralatan musik yang digunakan, seperti jedor, bendhe, kendang dan rebana. Dua yang disebutkan terakhir kiranya tidak perlu dibahas di sini, karena itu bukan peralatan pokok dan memang tidak ditemukan dimensi mistis atasnya. Namun, satu yang disebutkan pertama kiranya perlu mendapatkan pembahasan, sebab keberadaannya haruslah ada dalam kesenian.

Jedor adalah peralatan perkusi semacam bas drum yang memberikan bunyi pada jatuhnya tempo ketukan dan "chord". Ia terbuat dari bonggol pohon kelapa. Dipilih dengan ukuran besar dan dianggap cukup tua, sehingga cukup antep (berat), tidak ampang dan menghasilkan bunyi yang nyaring. Jedor ini sebelum digunakan biasanya di-sepub-kan terlebih dahulu untuk mengisi kekuatan gaib di dalamnya. Meskipun hal ini tidaklah wajib, tetapi alat ini secara umum dipahami memiliki kekuatan mistis. Nampaknya dalam batas tertentu jedor memiliki hubungan dengan masalah kesurupan. ${ }^{36}$

Kesurupan adalah hal yang biasa terjadi pada penari kesenian Kubrosiswo Bintang Mudo. Namun, kalau yang kesurupan adalah pemain musiknya, maka hal itu di luar kebiasaan. Untuk beberapa kasus sering ditemui penabuh jedor mengalami kondisi trance. Ketika ia kesurupan, alunan musik yang dimainkan menjadi kacau dan biasanya volume bunyi menguat. Tidak berapa lama orang tersebut akan bergabung dengan penari dan jedor akan diambil alih oleh pemain yang lain. Dengan kata lain, penabuh jedor mengalami kesurupan, tetapi penyebabnya bukan karena ia sedang menari. ${ }^{37}$

Orang-orang yang kesurupan yang tampaknya dalam kondisi tidak sadar, apabila diamati selalu memperhatikan bunyi jedor.

dengan tahlilan. Ketika kubrosiswo Bintang Mudo hadir beberapa dekade berikutnya, dalam beberapa sisi tampak terjadi penolakan yang kuat pada sebagian masyarakat karena dianggap tidak Islami.

${ }^{36}$ Menurut Muhbakir kegiatan menyepub peralatan musik pernah dilakukan. Penyepuhan ini dilakukan dengan cara ritual di tempat keramat desa, yaitu pancuran Kali Mbulu, tempat dimana diyakini akan keberadaan danyang desa yang bernama, Kyai Potro dan Nyai Potro. Menurutnya, ia sebenarnya tidak menyetujui tindakan ini, tetapi saat itu inisiatornya bukanlah orang Ngloho (sekalipun tidak disebutkannya secara eksplisit, tampak bahwa orang yang dimaksud dianggap memiliki keyakinan berbeda dengan orang Ngloho umumnya). Wawancara dengan Muhbakir, pendiri kesenian Kubrosiswo Bintang Mudo di Ngloho, Pringsurat, Temanggung pada 27 Juli 2019.

${ }^{37}$ Wawancara dengan Setiorini Rahma Safitri pada 27 Juli 2019. 
Kadangkala mereka mencari di mana sumber bunyi perkusi tersebut muncul. Banyak polah tingkah interaksi mereka dengan bunyi jedor. Ada yang maju ke arah sumber bunyi dengan berjalan pelan-pelan, ada yang sambil menari dan bahkan kadang ditemui sambil merayap. Ini artinya orang yang kesurupan sebenarnya sadar akan keberadaan bunyi. Namun, yang menjadi pertanyaan, apakah bunyi itu sendiri yang menstimulasi mereka ataukah kekuatan mistik ${ }^{38}$ dibalik jedor.

Stimulasi bunyi jedor dalam banyak kasus sangat berguna bagi kegiatan penyembuhan kesurupan. Banyak diantara orang kesurupan sangat sulit disembuhkan dengan cara normal (diberi doa), maka tidak jarang mereka oleh pawang didekatkan ke jedor. Bisa juga dalam hal ini orang yang kesurupan mendekat dengan sendirinya. Ketika mendekat, biasanya mereka akan masuk ke lubang jedor yang tidak dibalut kulit sapi. Tidak lama tampak tubuh lemas dan terbujur. Kondisi yang demikian menjadi tanda kalau mereka sudah tersembuhkan. ${ }^{39}$

Mengamati hal di atas, yang mana terdapat fakta penabuh jedor bisa kesurupan dan kemudian orang kesurupan bisa sembuh dengan cara masuk ke lubang jedor, maka apabila diterima asumsi kesurupan dikarenakan hal gaib, sulit untuk tidak mengatakan jedor tidak memiliki kekuatan mistis. Apalagi diketahui jedor harus selalu dialunkan agar yang kesurupan tidak mengamuk. Dalam hal ini, jedor seolah-oleh menjadi sumber kegaiban yang dapat mempengaruhi para pemain untuk bisa trance. Bunyi jedor baru boleh dihentikan jika semua yang kesurupan dipastikan telah tersembuhkan. ${ }^{40}$

\section{Makna Simbolik dalam Penyembuhan Kesurupan}

Kesurupan dalam perspektif individual memang membawa karakter yang melekat kepada setiap pemainnya. Terlepas sebenarnya di manapun mereka menggelar pertunjukan. Hal ini seolah

\footnotetext{
${ }^{38}$ Penelitian ini tidaklah mengansumsikan berada dalam sebuah keyakinan bahwa ada kekuatan mistik di balik keberadaan jedor, sebagaimana subyek penelitian meyakini. Hal tersebut jelas tidak empiris dan tidak dapat diverifikasi. Namun, sebagaimana perkataan Bryan S. Turner, terkadang penelitian harus berani mengambil satu langkah lebih maju untuk masuk ke dalam dunia subyek penelitian, justru agar obyektivitas penelitian dapat dicapai. Lihat, Bryan S. Turner, Sosiologi Islam Suatu Telaah Analitis Atas Tesa Sosiologi Weber (Jakarta: Rajawali, 1991).

${ }^{39}$ Diambil dari dokumentasi video Pertunjukan Kesenian Kubrosiswo Bintang Mudo Tahun 2014. Tidak dipublikasikan.

${ }^{40}$ Wawancara dengan Setiorini Rahma Safitri pada 20 Juli 2019.
} 
menahbiskan adanya "entitas gaib" yang selalu mengikuti orang yang kesurupan tersebut di manapun dia berada. Namun, dalam konteks pertunjukan yang terikat dalam ruang tertentu kadang dipahami faktor penyebabnya sangatlah lokal.

Orang-orang yang kesurupan ketika pertunjukan digelar di dusunnya, menampakan interaksi mereka dengan lingkungan sekitar. Terutama sekali tempat-tempat yang selama ini dianggap angker oleh masyarakat. Dalam hal ini, peristiwa yang tidak diinginkan, berupa larinya si kesurupan ke tempat keramat kadangkala terjadi. Grup kesenian Kubrosiswo Bintang Mudo, selalu berusaha menjaga agar mereka tidak lari dari panggung pertunjukan, tetapi beberapa diantaranya dapat lolos. Penjagaan ini sebenarnya dimaksudkan agar mereka yang kesurupan tidaklah bablas (hilang tidak diketemukan), karena ia sedang berada dalam kondisi yang dirinya sendiri tidak bisa mengendalikan. Kekhawatiran terjadinya bahaya yang bukan hanya fisik, tetapi mungkin kejiwaan, yaitu tersesatnya jiwa manusia ke jalan yang tidak benar. ${ }^{41}$

Memang sampai dengan penelitian ini dilakukan tidak ada orang kesurupan Kubrosiswo Bintang Mudo yang bablas, karena penjagaan yang ekstra ketat dilakukan oleh pemain lain dan kru. Namun, lolosnya mereka dari panggung pertunjukan kiranya perlu mendapatkan perhatian di sini. Biasanya tempat seperti kuburan, pancuran, sendang menjadi sasaran mereka. Tempat-tempat ini sebagaimana telah dijelaskan di atas dipercaya dikuasai oleh para danyang, yang mana dalam kondisi sehari-hari cenderung untuk dihindari.

"Pernah ada orang sini yang kesurupan, yang bernama Mahfud. Ia kalau kesurupan agak beringas berbeda dengan yang lainnya. Orang ini pernah melarikan diri ke kuburan Ngenthak (perkuburan desa). Di sana yang ditemui adalah kuburan Mbahnya yang sudah meninggal. Beberapa tempat keramat seperti pancuran Kalibening, Kali Mbulu juga sering menjadi sasaran orang-orang yang kesurupan." $\$ 42$

Dari pernyataan tersebut di atas, tampak bahwa eksistensi kepercayaan akan danyang-danyang desa berpengaruh terhadap pertunjukan. Danyang-danyang ini seolah-olah ikut hadir di mana

\footnotetext{
${ }^{41}$ Wawancara dengan Panis Dhbi Salam pada 10 Agustus 2019.

${ }^{42}$ Wawancara dengan Erwan Ladi Fani, tokoh pemuda Ngloho di Ngloho, Pringsurat, Temanggung pada 10 Agustus 2019.
} 
tempat pertunjukan kesenian digelar dan mempengaruhi orang-orang kesurupan. ${ }^{43}$

Selama ini warga Ngloho selalu menganggap bahwa biang kesurupan adalah setan. ${ }^{44}$ Nampaknya, konsep setan ini sangat dipengaruhi oleh pandangan Islam tentang makhluk gaib. Setan atau shaytä dalam bahasa arab diambil dari kata Shatana yang berarti jauh. Ada pula yang mengatakan dari kata (شَاطَ) yang berarti terbakar atau batal. ${ }^{45}$ Menurut 'Abbās Maḥmūd al-'Aqqād, kata shaytān merupakan kata Arab asli yang sudah sangat tua, bahkan boleh jadi lebih tua dari bahasa yang digunakan oleh selain orang Arab. ${ }^{46}$ Kata shaytan dikonsepsikan orang Arab pra-Islam sebagi makhluk halus yang mengajak kepada kesesatan. Hal ini tergambar dari ucapan Umm alJamil ketika menghina Rasulullah saat ia lama tidak mendapat wahyu. Berikut adalah ucapannya: "Apakah setanmu benar-benar telah meninggalkanmu?" Pada kalimat ini, Umm al-Jamil menyebut Jibril dengan shaytān. Kata shaytān dalam kalimat ini dipahami sebagai makhluk yang mengajak Muhammad keluar dari kepercayaan nenek

\footnotetext{
${ }^{43}$ Sebagai perbandingan dalam pertunjukan kesenian lain, dipercaya bahwa orang kesurupan terkadang bukan disebabkan dari danyang desa dimana pertunjukan digelar. Banyak danyang dari luar desa yang terkadang ikut merasuki para penari. Misalnya, menurut penuturan Mbah Rahman (tokoh spiritual desa Kebumen Temanggung), pernah menangani orang yang kesurupan yang menggelar sebuah seni pertunjukan di Dusun Medono, Pringsurat, Temanggung. Orang yang kesurupan tersebut menurutnya dirasuki arwah Wiropati - tokoh mitologis yang konon pernah hidup dan ikut berperang masa Diponegoro di abad XIX. Pawang grup kesenian tersebut telah mencoba untuk menyembuhkan, tetapi tidak ada yang mampu. Si kesurupan meminta untuk dihadirkan Mbah Rahman, baru ia mau pergi. Wiropati ini diketahui luas dalam mitos yang beredar, sebagai "robinhood" -kecugembong rampok yang berasal dari daerah Grabag Magelang. Medono dan Grabag adalah wilayah yang cukup berjauhan, tetapi "arwah" yang bersangkutan merasuki pertunjukan di Medono, tempat yang berada di luar hegemoni danyang desa Medono. Wawancara dengan Mbah Rahman, tokoh spiritual Dusun Kali Getas di Kali Getas, Kebumen, Pringsurat, Temanggung pada 10 Agustus 2019.

${ }^{44}$ Wawancara dengan Setiorini Rahma Safitri pada 10 Agustus 2019.

${ }^{45}$ Al-Hisyam, Firdaus, dan Rudi Hariyono, Kamus lengkap tiga Bahasa, Arab, Indonesia, Inggris (Surabaya: Gitamedia Press, 2006), 381.

${ }^{46}$ Pendapat ini digunakan oleh M. Quraish Shihab untuk memperkuat penjelasannya terkait kata shaytān yang terambil dari asal kata shatana. Dalam hal ini secara tidak langsung Quraish Shihab menolak pendapat yang mengatakan bahwa kata shaytān dalam kitab suci al-Qur'an terambil dari kitab-kitab wahyu terdahulu yaitu kitab orang Nasrani dan Yahudi. Lihat, Quraish Shihab, Yang Tersembunyi: Jin, Iblis, Setan dan Malaikeat (Jakarta: Lentera Hati, 2001), 21-22.
} 
moyang bangsa Arab. Dari penjelasan ini dapat disimpulkan bahwa pada masa pra-Qur'anik kata shaytan dikonsepsikan sebagai jin jahat. ${ }^{47}$ Pada periode Qur'anik kata shaytan masuk ke dalam sistem bahasa Alquran yang membangun konsep tersendiri pada pengguna bahasa tersebut dengan membawa makna dasar "jauh" dan makna relasionalnya sebagai sosok yang menjauhkan manusia dari kebenaran dan ketuhanan. shaytān dipahami sebagai sosok yang memusuhi manusia dalam hal penghambaan kepada Allah. Dalam Alquran sendiri dijelaskan bahwa Allah menciptakan shaytän untuk menguji keimanan manusia, untuk membedakan mana di antara mereka yang taat dan yang tidak seperti yang tertera pada QS. al-Hajj: 53:

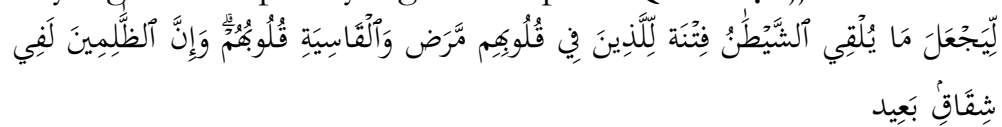

Artinya : agar Dia menjadikan apa yang dimasukkan oleh syaitan itu, sebagai cobaan bagi orang-orang yang di dalam hatinya ada penyakit dan yang kasar hatinya. Dan sesungguhnya orang-orang yang zalim itu, benar-benar dalam permusuhan yang sangat.

Beberapa arti setan dalam Alquran tersebut, diantaranya: pertama, setan berarti täghüt, yaitu segala sesuatu yang memalingkan dan menghalangi seseorang dari pengabdiannya kepada Allah dan rasulNya.48 Kedua, setan berarti para pemimpin kejahatan atau kekafiran. Di dalam Alquran orang yang menjadi tokoh jahat disebut setan. Bahkan mereka yang mengikutinya pun disebut juga setan. Hal ini nampak dalam QS. al-Baqarah: 14, yang artinya:

"Dan apabila mereka berjumpa dengan orang yang beriman, mereka berkata, "Kami telah beriman." Tetapi apabila mereka kembali kepada setan-setan (para pemimpin) mereka, mereka berkata, "Sesungguhnya kami bersama kamu, kami hanya berolokolok."

Ketiga, setan berarti setiap makhluk yang mempunyai karakter buruk yang menyebabkan manusia jauh dari kebenaran dan ketaatan kepada Allah dan rasul-Nya, yaitu kejahatan, kedurhakaan, kekufuran dan karakter buruk lainnya yang menyesatkan manusia. Dalam

\footnotetext{
${ }^{47} \mathrm{Umm}$ al-Jamil adalah istri dari Abū Lahab. Penjelasan mengenai ini dapat ditemukan dalam tafsir Imām 'Ali al-Ṣābūni. Lihat. Muḥammad b. 'Ali al-Ṣābūni, Safwat al-Tafasir, vol. 4 (Beirut: Dār al-Qur’an al-Karim, 1981), 572.

${ }^{48}$ Ayat-ayat Alquran yang menunjukkan tentang tăghūt juga dapat dijumpai dalam QS. al-Baqarah [2]: 256-257, QS. al-Nisā' [4]:51, QS. al-Mă'idah [5]: 60, QS. al-Naḥl [16]: 36, QS. al-Zummar [39]: 17.
} 
Alquran, setan digambarkan dalam banyak hal, misalnya: menakutnakuti manusia dan memerintahkan kepada kekejian (QS. al-Baqarah [2]: 286); merasuk ke dalam diri manusia dan menjadikannya tak tahu arah (QS. al-Baqarah [2]: 275); menggelincirkan manusia melalui amal perbuatan mereka sendiri (QS. Âli 'Imrān [3]: 155); menjadi sahabat buruk dan pendamping (QS. al-Nisā' [4]: 38; al-Zuhruf [43]: 36); menyesatkan manusia (QS. al-Nisā' [4]: 60), mengakibatkan kerugian yang nyata (QS. al-Nisā' [4]: 119); hanya menjanjikan tipuan (QS. alNisā' [4]: 120), menciptakan permusuhan dan kedengkian (QS. alMà'idah [5]: 91); menghiasi amal buruk manusia (QS. al-An'am [6]: 43); menjadikan manusia lupa (QS. al-An'am [6]: 68); menipu manusia (QS. al-A'räf [7]: 27); menuntun manusia agar semakin terpuruk (QS. al-A'räf [7]: 175), merusak hubungan antar saudara (QS. Yūsuf [12]: 100); mengingkari janji (QS. Ibrāhim [14]: 22), sangat kafir dan durhaka kepada Allah (QS. al-Isrā' [17]: 27; Maryam [19]: 44); mencampakkan pesimisme (QS. al-Haji [22]: 52); tidak akan menolong manusia (QS. al-Furqān [25]: 29); mengajak ke neraka (QS. Luqmān [31]: 21); menimpakan kepayahan dan siksaan (QS. Șad [38]: 41); memanjangkan angan-angan (QS. Muhammad [47]: 250); menanamkan rasa duka cita (QS. al-Mujādalah [58]: 10), Durhaka (QS. al-Nisā' [4]: 117); mengajarkan sihir (QS. al-Baqarah [2]: 102); menghasut untuk berbuat maksiat (QS. Maryam [19]: 83).

Kesadaran umat Islam tentang shaytän tidak lagi hanya terbatas pada makna jauh. Kata ini menunjuk pada sikap menjauh dari kebenaran. Dengan penjelasan Alquran, mereka telah mengkonsepsikan bahwa segala sesuatu yang menjadi penyebab kejauhan dari yang haqq (benar) adalah shaytä. ${ }^{49}$ Ini artinya setan dalam pemahaman Islam lebih kepada makna substansial, ketimbang persoalan wujud lahiriah. Secara wujud ia bisa berupa manusia maupun jin. ${ }^{50}$

Memang masyarakat Ngloho tidaklah semua memahami setan dalam terminologi keislaman. Namun, Islam sebagai kebudayaan yang

\footnotetext{
${ }^{49}$ Dalam sebuah hadis yang diriwayatkan oleh Imam A ḥmad, dari Abū Dharr, Rasulullah bersabda: "Wahai Abū Dharr, berlindunglah kepada Allah dari gangguan setan golongan manusia dan jin". Aku bertanya: "Wahai Rasulullah, apakah dari golongan manusia terdapat setan?" Beliau menjawab: "Ya”. Lihat, Sunan Aḥmad b. Hanbal, Hadis no. 20566.

${ }^{50}$ Shihab, Yang Tersembunyi, 120-121.
} 
hidup dalam masyarakat, jelas bahwa konsep setan yang dibayangkan mereka dipengaruhi kuat oleh pandangan Islam. Tentu saja ini menjadi menarik, sebab orang-orang yang kesurupan dalam kesenian Kubrosiswo Bintang Mudo diyakini disebabkan utamanya oleh setan, makhluk jahat yang bisa membawa kesesatan bagi manusia. Ini artinya kesurupan yang diyakini kerasukan oleh danyang desa, dalam batas tertentu dapat juga dipahami sebagai setan. Menjadi semakin jelas juga mengapa orang-orang Ngloho yang notabene berkebudayaan santri berupaya menghindari tempat-tempat angker di mana para danyang bersemayam. Bisa jadi maksudnya agar tidak terjerumus ke dalam bahaya setan. Demikian juga, ini menjadi alasan mengapa para pemain kubrosiswo Bintang Mudo selalu menjaga yang kesurupan agar tidak bablas. Tentu saja juga dengan maksud agar jiwa mereka tidak tersesat karena menyatu dengan setan. Di sisi lain, bahkan beberapa orang yang cukup islami menentang keberadaan kubrosiswo di desanya sejak awal karena adanya kesurupan ini. ${ }^{51}$

Kesurupan sebagai proses alamiah tidak mempermasalahkan oleh kelompok tersebut. Hanya saja jika kesurupan sebagai sebuah kesengajaan maka itu menjadi persoalan. Kesurupan dalam Kubrosiswo Bintang Mudo dapat dikatakan dalam pemahaman yang kedua, karena menyengaja berkegiatan seni, sehingga terjadilah kesurupan. Orang-orang yang kesurupan seringkali dipahami sebagai orang yang mushkil (mabuk, lupa kepada Tuhan). Hal ini tentu saja direlasikan dengan pandangan bahwa yang menjadi penyebab kesurupan adalah kekuatan yang bätil (buruk), yaitu setan. Tidak heran juga jika kemudian setan dalam hal ini dipahami sebagai makhluk jahat yang dapat mengalihkan perhatian manusia menjauhi Allah sekaligus menyesatkan.

\section{Ayat-ayat Alquran: Kekuatan Suci Bagi Penyembuhan Kesurupan}

Pada uraian sebelumnya telah dijelaskan bahwa penyembuhan orang keserupan dapat dilakukan menggunakan media jedor dan itu dianggap cara yang tidak normal, maka pembahasan kali ini akan diuraikan penyembuhan dengan cara normal. Cara ini biasanya disebut dengan istilah ditimbul, yaitu menggunakan doa-doa Islami yang berupa ayat-ayat Alquran. Kadang ia digunakan secara umum

${ }^{51}$ Wawancara dengan Setiorini Rahma Safitri pada 10 Agustus 2019. 
oleh orang Ngloho ketika ada orang yang kesurupan yang ada di luar kesenian.

Penyembuhan dengan cara ditimbul dalam kesenian Kubrosiswo Bintang Mudo ditemui dalam dua bentuk. Pertama, membacakan ayat-ayat Alquran di telinga si kesurupan kemudian ditiupkan. Kedua, melalui media air putih yang diberi doa terlebih dahulu dan kemudian disemburkan ke muka si kesurupan. Kadangkala air diberi bunga mawar. Apabila berhasil, si kesurupan akan tampak lemas dan terbujur ke tanah. Kemudian para kru akan membawanya ke back stage, menjauhi panggung sebagai upaya pengamanan agar tidak terganggu oleh penari lain yang kesurupan, sehingga proses penyembuhan dapat berjalan sebagaimana mestinya.

Ayat-ayat Alquran yang biasanya digunakan ketika kegiatan nimbul, seperti surat al-Ikhlạs, al-Fätiḥah dan ayat kursi. Tidak ada prioritas antara ayat satu satu dengan yang lainya. Penggunaannya bisa dilakukan secara bergantian. Apabila surat tertentu telah dicoba, tetapi si kesurupan belum sembuh, maka digunakan ayat yang lain. ${ }^{52}$ Biasanya pembacaan dilakukan tiga kali tiap-tiap surat. Berikut bentuk rapalan tersebut digunakan:

Cara pertama, surah al-Ikhlāṣ dibaca sebanyak tiga kali kemudian ditiupkan ke telinga. Apabila bacaan tersebut belum menyembuhkan kesurupan, maka dilakukan bacaan al-Fàtihah sebanyak tiga kali kemudian ditiupkan ke telinga. Demikian pula apabila yang kesurupan belum tersembuhkan, maka dilakukan pembacaan ayat kursi dengan jumlah ulangan yang sama dan ditiupkan ke telinga yang bersangkutan.

Dalam kasus tertentu, memang ditemui selain cara doa, banyak juga orang yang kesurupan meminta sesuatu sebagai syarat "makhluk halus" yang merasuki agar mau keluar. Bahkan kadangkala ia minta ditangani oleh orang tertentu. Dalam praktek demikian memang terdapat pandangan dalam masyarakat Ngloho akan makna Alquran. Kitab suci ini bukan hanya dipandang sebagai petunjuk, melainkan juga sarana penyembuhan. Dalam konteks ini Al-Qur'an secara umum sering disebut dengan istilah shifä' (penawar).

Di dalam Islam terdapat pandangan terkait Alquran sebagai shifä. Alquran sebagai shifa $\bar{a}$ setidaknya memiliki dua makna. Pertama, Alquran bermakna shifa dalam pemahaman bahwa keseluruhan Alquran

52Wawancara dengan Muhammad Faidzin pada 10 Agustus 2019. 
itu adalah penawar. Dengan kata lain, seluruh isi Alquran, baik secara maknawi, surat-surat, ayat-ayat maupun huruf-hurufnya dipahami memiliki potensi penyembuh atau obat. Hal ini sebagaimana terdapat dalam Alquran surah Yünus [10]: 57 sebagai berikut:
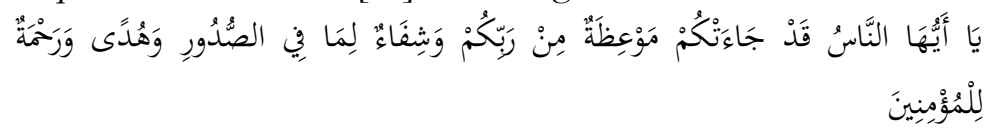

"Wahai manusia, sesungguhnya telah datang kepadamu suatu pelajaran dari Tuhanmu, dan penyembuh segala penyakit yang ada di dalam dada, dan petunjuk serta rahmat bagi orang-orang yang beriman."

Penyebutan kata "dada" pada ayat di atas sering diartikan sebagai hati. Hal itu menunjukan bahwa wahyu Ilahi tersebut berfungsi menyembuhkan penyakit-penyakit ruhani. Di dalam Alquran, hati ditunjuk sebagai wadah yang menampung rasa cinta dan benci, berkehendak dan menolak. Bahkan hati dinilai mampu melahirkan ketenangan ataupun kegelisahan. Adapun pada makna kedua, di mana kata shifa $\bar{a}$ secara khusus menggambarkan tentang obat dan penyembuh bagi pengimannya terdapat pada QS. al-Isra' [17]: 82,

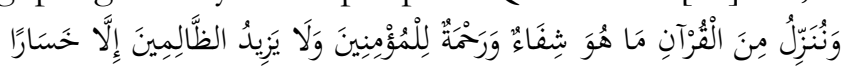

"Dan kami menurunkan sebagian dari Alquran sebagai obat dan rahmat bagi orang-orang yang beriman."

Dalam perspektif tektual historis, pengungkapan shifä dengan berbagai bentuknya disebutkan enam kali dalam Alquran. Lima di antaranya tergolong ayat Makkiah dan satu lainnya tergolong ayat Madaniah. Term shifa ini, pada dasarnya dipersandingkan dengan term marad. Pada umumnya, shifä diartikan dengan "sembuh", sedangkan marad diartikan dengan "sakit". Sakit dan sembuh merupakan sebuah keniscayaan dalamkehidupan umat manusia. ${ }^{53}$

Menariknya pandangan Alquran sebagai shifä dalam tataran kebudayaan tereksplanasikan dari pemaknaan hal-hal praktis. Alquran dalam hal ini sering dipahami memiliki kekuatan mistis, sehingga berguna bagi manusia. Orang Ngloho sering menyebutkan dengan istilah khadam, sebuah kekuatan suci yang bersumber dari Illahi. Ia

\footnotetext{
${ }^{53}$ Aswadi, Konsep Syifa' dalam al-Qur'an (Jakarta: Kementerian Agama RI Direktorat Jenderal Pendidikan Islam Direktorat Pendidikan Tinggi Islam, 2012), 6.
} 
dipahami bukan sebagai kekuatan hitam (bätil), tetapi kekuatan putih (baqq) ${ }^{54}$

Istilah khadam menurut Stoica Silviu adalah kata benda dari "khodum" atau "khadam", yang artinya "ilmu". Sebagai sebuah istilah diartikan sebagai "penjaga", sebuah terminologi untuk okultisme dalam pengetahun Islam. Lebih lanjut Stoica mengatakan bahwa khadam bukanlah animal spirit (roh binatang) dan tidak pula kekuatan sihir, serta ilmu dukun, melainkan malaikat penjaga yang menubuh dan menjaga huruf-huruf dalam Alquran. ${ }^{55}$

Pandangan ini mungkin saja secara luas diterima di Jawa, tetapi sebagai sebuah entitas budaya, tidak jauh berbeda terdapat juga di Ngloho. Kepercayaan mistis akan huruf-huruf Alquran terelasikan dengan keberadaan kekuatan suci, yaitu malaikat. Malaikat dipercaya sebagai salah satu makhluk gaib ciptaan Allah, tetapi ia memiliki karakter kepatuhan. Hal yang sering dibedakan dengan iblis, setan dan kadang jin sebagai makhluk pembangkang dan penggoda manusia untuk jauh dari kebenaran Allah. ${ }^{56}$

Hal ini sebenarnya dapat dipahami dengan teori emanasi, yang mana dalam kepercayaan sufistik, rembesan cahaya ke-Illahian terpancar pada mereka yang berada dalam jalan-Nya. ${ }^{57}$ Dalam persfektif tertentu, kekuatan ini kadang dipahami sebagai hadiah bagi orang-orang yang dekat dengan-Nya. Inilah yang sering disebut karämah dalam terminologi kewalian ${ }^{58}$. Karamah di sini dapat disejajarkan dengan konsep supernatural Max Weber dalam terminologi kharismatiknya sebagai kekuatan yang berada di luar

\footnotetext{
${ }^{54}$ Wawancara dengan Muhisam, warga Ngloho di Ngloho, Pringsurat, Temanggung pada 10 Agustus 2019.

${ }^{55}$ Stoica Silviu Valeriu, "Ilmu Khadam: The Occult Art of Accuiring and Directing Spirit Servants," "Salam http://www.academia.edu/37800447/Ilmu_Khadamthe_Occult_Art_of_Accuiring _and_Directing_Spirit_Servants_ILMU_KHADAM--ITS_PURPOSE. Diakses, 17 Juli 2019.

${ }^{56}$ Wawancara dengan Muhisam, warga Ngloho di Ngloho, Pringsurat. Temanggung pada 10 Agustus 2019.

${ }^{57}$ Abdurrahman Wahid, Menggerakkan Tradisi (Esai-Esai Pesantren) (Yogyakarta: LKiS Yogyakarta, 2007).

${ }^{58}$ Mawlānā 'Abd al-Raḥmān Jāmi', Ensiklopedi Tokoh Sufi (Warisan Spiritual Dan Keluburan Para Mabaguru Sufi) (Yogyakarta: Beranda, 2007).
} 
kemampuan manusia biasa yang terikat dalam wadah fisik. ${ }^{59}$ Oleh sebab, itu kekuatan mistis yang diyakini berada dalam Alquran yang kemudian dipersonifikasikan ke dalam makhluk gaib yang disebut malaikat, dapat dikatakan tidak lain adalah emanasi kekuatan Illahi itu sendiri. Darinya tidak heran jika itu kemudian dipandang sebagai kekuatan suci, kekuatan yang putih atau kekuatan yang benar (haqq).

Kekuatan yang bersumber dari Allah tersebut dalam pemahaman orang-orang Ngloho adalah kekuatan yang maha dahsyat. Segala ilmu mistik lain dianggap tidak mampu menandingi. Ilmu hitam yang mengajak manusia pada kejahatan dan diyakini berasal dari jin, iblis ataupun setan dipastikan akan tahluk olehnya, sebab Allah diyakini sebagai causa prima kehidupan atau sumber segala kekuatan, sedangkan jin, iblis dan setan hanyalah ciptaan-Nya.

Merelasikan fenomena penyembuhan kesurupan pada kuborosiswo dalam teks-teks kebudayaan, maka ada makna yang dapat dibongkar. Penyembuhan kesurupan pada hakikatnya adalah bertemunya dua kekuatan, yaitu kekuatan hitam (jahat) yang bersumber dari setan dan kekuatan suci (putih) yang bersumber dari Allah. Keberhasilan penyembuhan orang-orang yang kesurupan menggunakan ayat-ayat Alquran adalah bentuk simbolik ditundukkannya kekuatan hitam (jahat/ bätii) oleh kekuatan suci (haqq). Ini menjadi bentuk penegasan sebuah kekuasaan yang dominatif. Sebab, manusia dengan kelemahan fisiknya, ketika menyerahkan diri kepada Tuhan (causa prima), maka tidak ada kekuatan bätil yang mampu menyakiti. Dengan kata lain, penyembuhan kesurupan merupakan manifestasi simbolik keluhuran keimanan manusia kepada Sang Pencipta.

\section{Penutup}

Penyembuhan orang kesurupan pada dasarnya merupakan fenomena simbolik kebudayaan yang memiliki makna. Penyingkapan atasnya menunjukan hubungan relasional antara dua variabel, yaitu orang yang kesurupan dan ayat-ayat Alquran. Keduanya dipahami bukanlah sebagai fenomena material semata, melainkan berdimensi mistis. Masyarakat Ngloho mendefinisikan kesurupan sebagai kondisi tidak sadar diri yang dipengaruhi oleh makhluk halus. Makhluk ini

${ }^{59}$ Reinhard Bendix, "Refleksi Tentang Kepemimpinan Kharismatik," dalam Dennis Wrong (ed.), Max Weber Sebuah Khazanah (Yogyakarta: Ikon Teralitera, 2003), 257270. 
adalah mereka yang dalam pemahaman orang Jawa dianggap sebagai penguasa-penguasa kegaiban, seperti danyang, sing mbahurekso, pocong, kuntilanak, glundung pringis dan sebagainya. Dalam pemahaman Islami yang dianut oleh warga Ngloho semuanya disebut dengan istilah setan, makhluk jahat yang bertugas menggoda dan menyesatkan manusia.

Pemahaman lain akan fenomena penyembuhan kesurupan adalah penggunaan ayat-ayat Alquran. Mereka yang kesurupan dalam berkesenian Kubrosiswo Bintang Mudo biasanya disembuhkan dengan cara ditimbul, yaitu dibacakan ayat-ayat tertentu, seperti surah al-Fätiḥah, al-Ikhlạs dan ayat kursi. Keyakinan akan Alquran sebagai sarana penyembuhan sebenarnya dipengaruhi oleh pandangan Islam tentang Alquran sebagai shifä (penawar). Dalam bingkai kebudayaan, pendangan ini terinternalisasi ke dalam pemahaman bahwa hurufhuruf hijaiyah Alquran dianggap memiliki kekuatan mistik yang bersumber dari Allah.

Di sisi lain, yang menarik perhatian adalah keberadaan manusia yang juga dianggap makhluk ciptaan Allah. Manusia sebagai makhluk yang terikat dalam wadah fisik, ia dipahami sebagai insan yang lemah. Melawan kekuatan setan jelas berada di luar jangkauannya. Namun, menjadi lain ketika ia menyandarkan diri kepada kekuatan Allah. Dalam konteks penyembuhan kesurupan sebagai kemenangan yang haqq atas yang batili, dapat dikatakan bahwa ini terjadi sebagai konsekuensi penyerahan diri tersebut.

\section{Daftar Pustaka}

Ahimsa-Putra, Heddy Shri. Strukturalisme Levi-Strauss: Mitos dan Karya Sastra. Yogyakarta: Kepel Press, 2006

Al-Hisyam, Firdaus, dan Rudi Hariyono. Kamus Lengkap Tiga Bahasa: Arab, Indonesia, Inggris. Surabaya: Gitamedia Press, 2006.

Aswadi. Konsep Syifa' dalam al-Qur'an. Jakarta: Kementerian Agama RI Direktorat Jenderal Pendidikan Islam Direktorat Pendidikan Tinggi Islam, 2012.

Bendix, Reinhard. "Refleksi Tentang Kepemimpinan Kharismatik". Dalam Dennis Wrong (Ed.). Max Weber Sebuah Khazanah. Yogyakarta: Ikon Teralitera, 2003.

Burhannudin, Jihan. "Identitas Kesenian Tradisional Kubro Siswo Di Dusun Sedayu II, Sedayu, Muntilan, Magelang. Skripsi. Yogyakarta: Universitas Islam Negeri Sunan Kalijaga, 2016. 
Effendie, Machmoed. "Unsur Budaya Santri Dalam Seni: Studi Pendahuluan Tentang Seni Pertunjukan Rakyat Kobra Siswa Di Magelang”. Laporan Penelitian. Yogyakarta: Fakultas Ilmu Budaya Universitas Gadjah Mada, 2001.

Faidi, Ahmad. "Qashidah Burdah sebagai Media Pengobatan MagisEkonomis: Studi Terhadap Tradisi Pembacaan Qashidah Burdah terhadap Orang Sakit di Desa Sera Timur Kecamatan Bluto Kabupaten Sumenep Propinsi Jawa Timur", Dalam Millati, Journal of Islamic Studies and Humanities, Vol. 1, No. 1 (2016).

Foley, Kathy. "The Dancer and the Danced: Trance Dance and Theatrical Performance in West Java." Asian Theater Journal. Vol. 2. No. 1 (1985).

Geertz, Clifford. The Interpretation of Cultures. New York: Basic Group. 1973.

Hadi, Abdul. "Bacaan Al-Qur'an sebagai Pengobatan: Studi Living Qur'an Pada Praktik Pengobatan Di Ds. Keben Kec. Turi Kab. Lamongan Jawa Timur". Skripsi. Yogyakarta: Fakultas Ushuluddin dan Pemikiran Islam UIN Sunan Kalijaga, 2015.

Jami, Mawlana 'Abd ar-Rahman. Ensiklopedi Tokoh Sufi (Warisan Spiritual Dan Keluburan Para Mahaguru Sufi). Yogyakarta: Beranda, 2007.

Kartika, Dharsono Sony. Pengantar Estetika. Bandung Rekayasa Sains, 2004.

Kartomi, Margaret T. "Music and Trance in Central Java." Ethnomusicology. Vol. 17. No. 2 (1973).

Mahfudh, Hasan. "Dari 'Ābid al-Jābiri tentang Epistemologi Arab Islam.” Dialogia: Jurnal Studi Islam dan Sosial. Vol. 13. No. 1 (2015).

Mansur, Muhammad, dkk. Metodologi Penelitian Living Qur'an dan Hadis. Yogyakarta: Teras, 2007.

Muktadin, Baytul. "Untuk Pengobatan Penyakit Jiwa: Studi Living Qur'an Di Desa Kalisabuk Kesugihan Cilacap Jawa Tengah". Tesis. Yogyakarta: Program Pascasarjana UIN Sunan Kalijaga, 2015.

Șabūni (al), Muhạmmad b. 'Ali. Șafwat al-Tafâsìr. Beirut: Dār al-Qur'àn al-Karim, 1981.

Safitri, Setiorini Rahma. "Apresiasi Masyarakat Santri Ngloho Terhadap Kesenian Kubrosiswo Bintang Mudo Di Ngloho Pringsurat Temanggung”. Tesis. Semarang: Program Pascasarjana Universitas Negeri Semarang, 2017. 
Salam, Panis Dhibi. "Pola Interaksi Kyai Santri: Studi Determinasi Kewibawaan Kharismatik Kyai dan Pengaruhnya Terhadap Hasil Belajar Santri". Skripsi. Semarang: Universitas Negeri Semarang, 2009.

Shihab, M. Quraish. Membumikan Al-Quran. Bandung: Mizan, 1992. . Mukjizzat Al-Quran. Bandung: Mizan, 2001. . Yang Tersembunyi: Jin, Iblis, Setan dan Malaikat. Jakarta: Lentera Hati, 2001.

Suseno, Franz Magnis. Etika Jawa: Sebuah Analisis Falsafi Tentang Kebijaksanaan Hidup Jawa. Jakarta: Gramedia, 1984.

Turner, Bryan S. 1991. Sosiologi Islam: Suatu Telaah Analitis Atas Tesa Sosiologi Weber. Jakarta: Rajawali.

Wahid, Abdurrahman. Menggerakkan Tradisi (Esai-Esai Pesantren). Yogyakarta: LKiS Yogyakarta, 2007.

Winarti P., Sri. Sekilas Sejarah Keraton Surakarta. Surakarta: Cendrawasih, tt. 